NBER WORKING PAPER SERIES

\title{
ORGANIZATIONAL COMPLEXITY AND BALANCE SHEET MANAGEMENT IN GLOBAL BANKS
}

\author{
Nicola Cetorelli \\ Linda S. Goldberg \\ Working Paper 22169 \\ http://www.nber.org/papers/w22169
NATIONAL BUREAU OF ECONOMIC RESEARCH
1050 Massachusetts Avenue
Cambridge, MA 02138
April 2016

The views expressed in this paper are those of the individual authors and do not necessarily reflect the position of the Federal Reserve Bank of New York, the Federal Reserve System, or the National Bureau of Economic Research. Address correspondences to Nicola Cetorelli or Linda S. Goldberg, Federal Reserve Bank of NY, Research Department, 33 Liberty St, New York, N.Y. 10045, U.S.A. email: Linda.Goldberg@ ny.frb.org or Nicola.Cetorelli@ny.frb.org. We gratefully acknowledge the excellent data work of Rose Wang and Sam Stern. Our work benefited from the insights of seminar participants at the Federal Reserve Bank of New York, the Federal Reserve Bank of Chicago, the Bank for International Settlements, Columbia Business School, Hitotsubashi University, MOFIR Conference in Kobe Japan, the University of North Carolina, the International Banking Research Network, Banca d'Italia, Bank of Canada, and Bank of Japan.

NBER working papers are circulated for discussion and comment purposes. They have not been peer-reviewed or been subject to the review by the NBER Board of Directors that accompanies official NBER publications.

(C) 2016 by Nicola Cetorelli and Linda S. Goldberg. All rights reserved. Short sections of text, not to exceed two paragraphs, may be quoted without explicit permission provided that full credit, including $\odot$ notice, is given to the source. 
Organizational Complexity and Balance Sheet Management in Global Banks

Nicola Cetorelli and Linda S. Goldberg

NBER Working Paper No. 22169

April 2016

JEL No. F3,G15,G21

\begin{abstract}
$\underline{\text { ABSTRACT }}$
Banks have progressively evolved from being standalone institutions to being subsidiaries of increasingly complex financial conglomerates. We conjecture and provide evidence that the organizational complexity of the family of a bank is a fundamental driver of the business model of the bank itself, as reflected in the management of the bank's own balance sheet. Using microdata on global banks with branch operations in the United States, we show that branches of conglomerates in more complex families have a markedly lower lending sensitivity to funding shocks. The balance sheet management strategies of banks are very much determined by the structure of the organizations the banks belong to. The complexity of the conglomerate can change the scale of the lending channel for a large global bank by more than 30 percent.
\end{abstract}

Nicola Cetorelli

Federal Reserve Bank of New York

33 Liberty Street

New York, NY 10045

nicola.cetorelli@ny.frb.org

Linda S. Goldberg

Federal Reserve Bank-New York

33 Liberty Street

New York, NY 10045

and NBER

linda.goldberg@ny.frb.org 


\section{Introduction}

In a traditional setting, banks are entities whose business model is predominantly defined by their deposit taking and loan making operations. The balance sheet of such entities largely defines what a bank is and what a bank does, and understanding banks' overall balance sheet management - from funding and liquidity strategies to sensitivity to investment opportunities - has been the focus of analysis of a vast and well-established literature.

While extremely broad and diverse in scope, a fairly distinctive feature of this literature is the focus on banks' own characteristics (e.g., balance sheet size, asset composition, liability structure, its own governance, etc.) to explain observed patterns in balance sheet management and choice of business model. This approach has been perfectly legitimate, at least with historic applications to U.S. data, since across time the typical banking firm has been either a standalone entity or a commercial bank subsidiary in simple, bank-focused bank holding companies (BHCs). But while there is certainly still a large number of banks fitting the mold of simple organizations, there has also been the progressive emergence and growth of complex financial conglomerates, where a bank may be just one of many - at times thousands - related affiliates (Cetorelli and Goldberg, 2014; Cetorelli, McAndrews and Traina, 2014). In this paper we conjecture that the organizational complexity of the family a bank is part of is a fundamental driver of the business model of the bank itself, as reflected in the management of its own balance sheet.

Why should the organizational structure of the corporate family matter for the business model of its bank subsidiaries? One possibility is that it doesn't. Perhaps conglomeration is merely a manifestation of scale. As an entity grows in size it may just expand its organizational footprint, but the separate "parts" are just run independently of one another. Or it may be that the driver behind conglomeration is to achieve diversification, whereby subsidiaries are on their own while, by virtue of aggregation, the whole organization achieves reduced return variability. If that were the case, then we would expect banks, irrespective of the organizational structure of their families, to operate according to the canonical model mentioned above: the bank is a profit center, engaged predominantly in exploiting investment (e.g., lending) opportunities, and it manages its own 
balance sheet accordingly.

Conversely, one could speculate that firms organize themselves as complex conglomerates because there may be synergies and complementarities across the different subsidiaries that extend beyond diversification. Because of these complementarities, the individual subsidiaries are not run independently of one another but instead take familywide considerations into account while managing their own activities. This conjecture is rooted in the literature on the theory of the firm: Organizational form should emerge endogenously depending on the intensity of informational and other agency frictions that may exist within the organization on the one hand, and the relative importance of crossbenefits to linking together separate lines of business activity on the other. These tradeoffs have been explicitly laid out, for instance, in Stein (2002) and Rajan and Zingales (2000, 2001a, 2001b). The main takeaway of these contributions is that if we observe a firm with a complex organizational structure, such as one that ties together a large count of different subsidiaries, then it must be the case that internal complementarities and mutual dependencies are sufficiently large to justify the costs associated with the associated agency frictions ("... what is needed are links that cause the person or unit to be better off voluntarily following the firm's commands rather than going their own way ...", Rajan and Zingales, 2000, p. 19). ${ }^{1}$ If that is the case, the complexity of a conglomerate should impose a constraint on its subsidiaries' business choices. The implication is that, all else equal, their own balance sheet should exhibit relatively lower sensitivity to changes in market conditions. While we are not aware of contributions that have looked explicitly at the role of organizational complexity on the business conduct of banks, the literature on organizational form and efficiency does provide evidence consistent with this conjecture. For example, Ozbas and Scharfstein (2010) show that subsidiaries that are part of conglomerates respond less to investment opportunities than otherwise similar, standalone entities.

\footnotetext{
1 This point delineating the issue of establishing the allocation of control within a hierarchy, and its possible delegation, is made broadly in other related contributions. For instance, Hart and Moore's (2005) model of hierarchy suggests how chains of command and centralization of decision within an organization is likely to emerge naturally. But even in settings where it may be optimal for authority to be delegated, the decision making process may necessarily present some degree of mediation among the different parts of the organization (e.g., Aghion and Tirole, 1997). This impact on conduct is also found in models describing the effort by subordinates to influence the decision making process internal to the organization (e.g., Milgrom, 1988, Milgrom and Roberts, 1988).
} 
How would one test this conjecture specifically on banks? Take for instance a bank that is on the receiving end of a funding shock. Traditional analysis suggests that the balance sheet impact of such shock will depend ultimately on certain characteristics of the bank itself: for example, perhaps due to differences in asset size, certain banks may have more or less unencumbered access to external sources of funding to begin with, so that the same shock may have a larger impact on funding on some banks than others (e.g. Kashyap and Stein, 2000). We then expect this shock to be transmitted on the asset side of banks' balance sheet, yielding a differential prediction regarding their investment (lending) sensitivity to the initial shock. For the standalone banks or for banks that are part of simple, bank-centered BHCs, we expect to be able to trace the impact of that initial funding shock as a function of banks' own balance sheet characteristics. However, for the argument above, an otherwise identical bank that is part of a complex organization should react to the same funding shock by also factoring in the organizational characteristics of the family it is part of, thus exhibiting reduced overall balance sheet sensitivity.

This is a testable prediction associated with organizational complexity that can be brought to the data. We proxy organizational complexity with the count of subsidiaries that the conglomerate owns (Cetorelli and Goldberg, 2014; Carmassi and Herring, 2015). We approximate ideal testing conditions using micro data for global banks that operate branches in the United States. For these branches we have full financial data, and for each of them we collect information about the organizational structure of their parents. Our experiment relies on an exogenous, positive shock in funding supply that occurred in late 2010. At that time the Federal Deposit Insurance Corporation (FDIC) implemented a significant change in the rule used to impose its assessment fee on U.S. banking institutions benefiting from deposit insurance. The new rule, aimed at taxing U.S. banks' reliance on wholesale funding, all else equal, led to a documented significant shift in demand by U.S. banks away from wholesale liabilities and toward insured deposits. U.S. branches of foreign banking organizations (FBOs) were outside the scope of the FDIC ruling, as they are prohibited from holding insured deposits and are exclusively reliant on wholesale funding for their operations. Consequently, FBOs turned out to be on the receiving end of a truly exogenous, positive funding shock that resulted from the reduction in the cost of wholesale funding (Kreicher, McCauley, and McGuire 2014). 
We then trace the impact of this shock on the balance sheet of the FBO branches, focusing in particular on the sensitivity of their lending portfolios. Our empirical investigation supports the conjectured effects of organizational complexity. Branches of conglomerates in more complex families have a markedly lower lending elasticity to the wholesale funding shock of 2010. This result is robust to alternative definitions of lending activity. It is also robust to refinements in the metric of organizational complexity, proxied by total subsidiaries count, whereby exploiting various geographic considerations we acknowledge the fact that not every single subsidiary contribute to the overall complexity of the conglomerate. First, we argue that if a conglomerate has subsidiaries (also) located in the U.S., or located in countries that closely co-move with the U.S., there may be reduced scope for the U.S. bank branches to provide internal liquidity support. Hence, a bank affiliate in an otherwise complex conglomerate but with a large fraction of subsidiaries in the U.S. or in countries co-moving with the U.S. should exhibit a relatively higher degree of independence in its own balance sheet management. Similarly, an organization may expand its subsidiary count to circumvent taxation or regulation, without those affiliates necessarily adding "economic" complexity that matters for bank behavior. In that case we would also expect bank affiliates to display a relatively more independent balance sheet management the higher the share of non-economic affiliates.

We also check that the reduced investment sensitivity of the branches in more complex families is not just driven mechanically by a spurious trend differential in lending growth. Finally, we allow for concomitant events, besides the purported funding shock, that might have led to a relatively lower lending growth for the branches of more complex families, including changes in economic and/or funding conditions affecting the parent organizations in their own home countries. We show that the balance sheet management strategies of banks are very much determined by the structure of the organizations they belong to. Indeed, the complexity of the conglomerate can change the scale of the lending channel for a large global bank by more than 30 percent.

Our research complements several threads of literature specific to banking. First, it relates naturally to the problem of liquidity management, and specifically to the existence and operation of internal capital markets within a bank. Banks actively manage liquidity, allocating funds across offices in different geographic locations and based on relative needs 
(Cetorelli and Goldberg, 2011, 2012a, 2012b). ${ }^{2}$ Cetorelli and Goldberg (2012c) pushed further in understanding the corporate drivers behind liquidity management, suggesting that a bank would not move funds indiscriminately in and out of its offices in response to a liquidity shock, but rather it strategically reshuffles funds from locations that the bank had assigned a funding source role to locations identified as investment sinks. This paper offers further important insights into this decision problem, suggesting that the organizational characteristics of the broader corporate structure of the BHC may be fundamental determinants of the extent to which that bank engages in active liquidity management.

Second, this perspective on organizational structure offers an innovative contribution into the research on bank lending, its relationship with the funding side of the balance sheet, in turn related to the literature on the bank "lending channel". While our previous research emphasized the importance of the global bank business model for the measured bank lending channel, in the present paper we provide the significant refinement that the sensitivity of banks' investment activity to funding shocks will depend on the characteristics of the organization that controls the bank. The specific message is that the bank lending channel, at least in its standard form of lending external to the organization and to domestic counterparties, is expected to be weaker for global banks in more complex organizations.

Section II lays out the details of our identification strategy and shows how the U.S. branches of foreign banks satisfy the criteria needed for identifying the role of the broader organization's complexity for liquidity management. Section III introduces the data while Section IV provides the evidence linking organizational complexity to bank balance sheet management, showing the differential sensitivity of branches own lending to the funding shock in relation to organizational structure. Section $\mathrm{V}$ presents the robustness tests mentioned earlier, and Section VI concludes with broader implications for research and policy.

${ }^{2}$ See also Kerl and Koch (2015), Pawłowska, Serwa, and Zajączkowski (2015), Wong, Tsang and Kong (2015), and Düwel and Frey (2012). 


\section{Identification strategy}

The conjecture described in the introduction yields testable predictions on the balance sheet management of a bank. If one could identify an exogenous shock to the funding supply of the bank, then all else equal, banks in more complex conglomerates should exhibit a relatively muted lending response to the same shock. While this prediction is fairly straightforward, testing it requires imposing challenging conditions on the data. Specifically, the following circumstances should be approximately true: first, a funding shock should be specific to banks' own balance sheet, and therefore unrelated to conditions in other markets where the family operates and unrelated to changes in liquidity needs by the parent organization. This condition is relevant for the particular conjecture to be tested, as we already know that in times of need, corporations activate internal capital markets. However we want to test how a bank affiliate manages its own balance sheet, in terms of funding choices and related investment decisions, and how the complexity of the parent organization affects such choices, but we do not want to capture a reaction to changes in the conditions of the parent organization itself.

Second, and related, the shock should be a "normal" one, so that a bank's typical response is observed, rather than a reaction to exceptional circumstances such as those arising during crisis times, when public sector interventions and market disruptions may confound identification. Third, the funding shock should be ideally unrelated to banks' own characteristics, and therefore to their intrinsic ability to access funding. Fourth, because we want to trace the effect of a funding shock on banks' asset side, the funding shock should also be unrelated to local market conditions, thus assuring that we are picking up a loan supply effect rather than a simple adjustment to loan demand. Finally, a proper identification strategy requires the choice of the right organizational "unit" of analysis. Our goal is to observe and compare a cross section of banks characterized by heterogeneous parent conglomerates. However, the banks themselves may have influence or control over their own subsidiaries within a hierarchical organizational structure. While this is in principle a facet of complexity of the parent organization that is worth analyzing independently, we focus on complexity "from above", that is, related to the overall number of subsidiaries of the parent organization. We rely on balance sheet information for the U.S. 
branches of foreign banking organizations. This focus avoids the potential operational constraint for a bank coming from having its own controlled entities. The next two subsections present in detail our identification strategy.

\section{II.1. U.S. Branches of foreign banks as the right unit of analysis}

The branches of foreign banks operating in the U.S. are by definition simpletons, that is they are direct extensions of a bank but do not have downstream subsidiaries. This feature allows us to isolate the potential effect of the organizational structure "above" the entity in an organizational tree without having to worry about confounding effects from complexity "below". Likewise, the branch would not be in charge of organization-wide decisions about the structure and complexity of the organization of the financial conglomerate to which it belongs.

U.S. branches of foreign banks are also significant economic units. In 2010, the time around our experiment, the median U.S. branch of a foreign bank had $\$ 730$ million in assets. By comparison, the median U.S. commercial bank at the same time period had $\$ 150$ million in assets. The U.S. branches of foreign banks are also economically relevant in aggregate. In 2010, the ratio of total assets of foreign-banking-organization branches to total assets of domestically-owned U.S. commercial banks was about $17 \%$ and the lending ratio was $8 \%$. These entities comprise a significant component of bank credit to the U.S. real economy.

Finally, by focusing on the business conduct of U.S. branches of foreign banks, we have a natural distinction between the market of operation of the unit of analysis and the (global) markets where the parent conglomerates operate. ${ }^{3}$

\section{II.2. 2010 FDIC ruling on deposit insurance assessment fee as exogenous funding shock}

In November 2010, the Federal Deposit Insurance Corporation (FDIC) announced a significant change in the criteria utilized for calculating the assessment fee that U.S. chartered banks pay for their access to deposit insurance (FDIC, 2011). Prior to this

\footnotetext{
${ }^{3}$ In the empirical implementation we account specifically for the extent to which the parent conglomerates have other subsidiaries located in the U.S.
} 
change, a U.S. bank had paid a deposit insurance assessment fee proportional to the amount of insured deposits that it held on its balance sheet. The proposed ruling released in November 2010, and which went into effect in February 2011, changed the assessment base from just insured deposits to total liabilities, calculated as total assets minus tangible shareholders' equity. The broadening of the liability base was intended to eliminate a prior cost disadvantage of insured deposits relative to wholesale funding via the premium structure. The original distortive rule had contributed to creating the incentive for U.S. banks to increasingly rely on wholesale funding sources. After the global financial crisis, there was an increased recognition that wholesale funds were prone to greater volatility and exposed banks to greater liquidity risk. The rule change led to a decline in FDICinsured banks' exposure to liquidity risk, and reduced the potential burden on the FDIC and taxpayers in the event of realized default. ${ }^{4}$

In the quarters that followed the proposed ruling, U.S. banks increased the average deposit-to-asset ratio by 7 percentage points (from 66 to 73 percent), an increase of a magnitude hardly ever recorded before, and reduced accordingly their reliance on wholesale funding at current interest rates. The associated decline in overnight interest rates on wholesale funding from this decline in demand was estimated to be between 5 and 10 basis points (Kreicher, McCauley and McGuire 2014).

U.S. branches of foreign banks do not have access to deposit insurance and are prohibited from taking in insured deposit liabilities. ${ }^{5}$ Hence, because of their virtually exclusive reliance on wholesale funding, the FDIC ruling and the subsequent reduced demand for wholesale funds by U.S. banks represented a positive and exogenous funding shock for the U.S. branches of foreign banks. For these branches, this shock indeed meets all the requirements mentioned above to approximate the conditions for a quasi-natural experiment. The FDIC ruling came as a specific requirement in the Dodd-Frank Act. Because the FDIC had been mandated to implement the reform, the circumstances that led

\footnotetext{
${ }^{4}$ Moreover, because wholesale funding was disproportionately held by large institutions, the reform had the intent of reducing the burden on smaller and less complex U.S. chartered banks and raising the burden on large banks (Gruenberg 2011).

5 The prohibition to access deposit insurance was sanctioned in the Foreign Bank Supervision Enhancement Act of 1991 (FBSEA). The FBSEA established a grandfather rule creating an exception for deposit balances in existence before December 19, 1991. However, the actual size of such deposits is extremely small and therefore not material for our analysis.
} 
to the ruling were reasonably orthogonal to conditions in markets where branches operated at the time, and a fortiori were orthogonal to market conditions in which their foreign-based financial organizations were active.

Given the institutional nature of the ruling, we can also comfortably assume that the positive funding shock is unrelated to loan demand conditions experienced by branches at the same time. Furthermore, because branches of foreign banks were passively on the receiving end of this funding shock, we can also assume that the shock was unrelated to branches' own conditions that might have changed their relative access to funding sources.

Finally, the ruling meets the conditions of a "normal" shock: The impact on wholesale funding was detected but was not the result of exceptional, crisis-like conditions. It is reasonable to posit that the observed response by branches would be the result of their normal operations and not a response to extraordinary circumstances.

\section{Data}

Data on the balance sheets of U.S. branches of FBOs are collected from their quarterly regulatory filings (the FFIEC 002). We select for our baseline analysis the period between $2010 q 1$ and 2012q1 in order to have a period centered around the FDIC ruling while avoiding falling into crisis quarters earlier on. These regulatory filings also contain identifiers needed to establish the organizational links with the branches' ultimate "high holder parents." Using these identifiers, we accessed Bankscope's Ownership Module and compiled detailed information about the structure of each organization. ${ }^{6}$

Table 1 provides summary statistics of the population of U.S. branches of foreign banks and of their corresponding parent organization. Over the time period of analysis, there were 132 FBOs that had a total of 204 branches in the United States. The normal mode of operation is for an FBO parent to operate in the U.S. with one branch of one of its (foreign) bank subsidiaries. ${ }^{7}$ For example, Credit Suisse Group headquartered in

\footnotetext{
${ }^{6}$ Data is for 2012q4. Given the relatively short time period of the analysis it made sense to just have a static cross section of organizational data. Spot checks demonstrated that in fact structures stayed fairly stable over the sample period.

${ }^{7}$ Some FBOs may also enter and operate by establishing U.S.-chartered bank holding companies and/or U.S.chartered commercial banks. For identification purposes we maintain our focus on U.S. branches, but we incorporate information about the total U.S. "footprints" of FBOs in our analysis.
} 
Switzerland owns Credit Suisse bank, also headquartered in Switzerland, which operates a branch located in New York. However, some of these foreign conglomerates operate with multiple branches within the United States, hence the larger branch count with respect to FBO count. In fact a small subset of thirteen FBOs operates branches through more than one bank subsidiary. For example BBVA operates four U.S. branches through three subsidiaries: one subsidiary in Spain owns a branch in New York, another subsidiary in Mexico owns a branch in Texas, and a subsidiary in Hong Kong owns two branches, one in California and another in New York. While cross-branch, internal dynamics may be interesting to study, for the purposes of our analysis we aggregate the balance sheets of all branches up to their common commercial bank, and treat that as our unit of analysis. ${ }^{8}$

U.S. branches of FBOs are economically significant, accounting in the time period of analysis for more than $\$ 1.8$ trillion of U.S. banking assets (see Table 2). While the branches are part of organizations originally from every part of the world, the branches with the highest balance sheet size have parent organizations in Europe, Japan and Canada. The parent organizations also display marked heterogeneity. By asset size, high holders from Europe and Asia are the largest and contain the most global systemically important financial institutions.

Measuring the complexity of the organizational structure of financial conglomerates requires information on related entities and details about ownership and control. Given the multi-country span of the organizations, we follow Cetorelli and Goldberg (2014) and for each financial conglomerate extract relevant organizational details from Bankscope's Ownership Module. ${ }^{9}$ We take a conservative approach to measuring organizational complexity and define a subsidiary as part of an organization if the parent has 50 percent or more ownership. Lowering the ownership threshold to include cases of control with minority ownership does not affect the quality of the analysis. Hence, the count of entities with at least 50 percent of ownership is our basic measure of organizational complexity. ${ }^{10}$

\footnotetext{
8 Performing the analysis at the individual branch level does not materially affect the quality of our results.

9 This information includes affiliate name, percentage of ownership by the immediate parent or a related control categorization, geographic location, and type, both as assigned by Bankscope and as a NAICS code for the main industry to which an affiliate is assigned (information as of the end of 2012).

${ }^{10}$ Additional complexity measures are considered in Section V.
} 
The foreign banking organizations have highly differentiated structures. The broad features of counts of entities are visible in the box and whisker representations of Chart 1. The exhibit first divides the organizations into quintiles according to entity count, and then the boxes show the ranges of the quintiles as well as the central values of counts within each. The first quintile is comprised of simple organizations, containing on average 6.4 entities, despite being global banking organizations. Indeed, the lower 3 quintiles of organizations are each comprised of less than one hundred entities satisfying the criteria of at least 50 percent ownership. About one quarter of the sample (35 of the conglomerates) contains in excess of 100 affiliates. Within the $5^{\text {th }}$ quintile, ten of the financial conglomerates contain between 1000 and 2800 entities. The most complex financial conglomerates, by affiliate counts, are sourced from the euro area and the United Kingdom. By contrast, many of the organizations from Asia and the Americas have fewer than 25 affiliates.

Cetorelli and Goldberg (2014) have shown that the size and complexity of financial conglomerates are correlated, but not tightly so. Larger asset size organizations (as ranked by assets of the BHC) also tend to have many more legal entities, but with considerable variation even for the same size BHC. The clouds of dots around a fitted regression line illustrate the dispersion across firms (Chart 2), with assets explaining only 48 percent of the cross-sectional variation in organizational counts. We capitalize on this structural difference in our subsequent econometric analysis, where we seek and establish a separate role for size and complexity.

We use the subsidiary count as our metric of organizational complexity, which is consistent with the organizational theories described earlier. The larger the number of separate entities that are organized under common ownership and control, the more intense the potential complementarities across those entities and consequently the higher the degree of dependency of each individual subsidiary to the broader business strategy of the whole organization. Of course the relationship does not have to be linear and threshold effects may exist as well, but this is an empirical issue that can be brought to the data. But by and large we posit that subsidiary count is a good proxy for our purposes. ${ }^{11}$

${ }^{11}$ In the robustness section we further discuss the choice of subsidiary count and provide refinements to this metric that exploit specific geographic and industry characteristics of the full range of subsidiaries. 


\section{Results}

The conjecture developed in section II implies differential investment sensitivity in response to a funding shock, as a function of its family's organizational complexity. We implement this test as follows. We combine the data of individual branches within the U.S. to their common bank parent and refer to this aggregate branch as our unit of analysis. For each branch we define Pre-shock lending aggregates as averages across 4 quarters prior to the FDIC assessment change implementation. We then define as Post-shock aggregates the corresponding averages across 4 quarters post FDIC implementation (we exclude the quarter of implementation, 2011q1). The quarterly average has the advantage of smoothing out idiosyncratic variability over time for each branch. We then construct PrePost dependent variables as the growth rate of each lending aggregate between the Post and the Pre periods. The regression specification below formalizes this identification strategy:

$$
\Delta Y_{\text {Pre-Post }}^{i j}=\beta_{0}+\beta_{1} \cdot \text { complexity }^{j}+\beta_{2} \cdot \text { Controls }^{j}+\beta_{3} \cdot \text { Controls }^{i}+\varepsilon^{i j}
$$

Where $\Delta Y^{i j}$ is lending growth of branch $i$ belonging to family $j$. Complexity is measured as the (log) of the total count of subsidiaries owned by the family. According to the conjecture, the estimated coefficient $\beta_{1}$ should be negative and significant. Total family asset size is part of the vector Controls $^{j}$, while Controls ${ }^{i}$ is a vector of branches' own characteristics. We include total branch assets as a standard metric of the size of branches' balance sheet, which should have itself a role in determining branches' investment sensitivity. As customary in analyses of banks' lending sensitivity to funding shocks, we also include the share of liquid assets (cash and securities) to total assets to allow for varying strategies in terms of liquid buffer holdings.

We begin by presenting results of specification (1) using commercial and industrial (C\&I) lending as the dependent variable. Across all specifications in Table 3, the estimate of the constant is positive, indicating that branches experienced a positive funding shock overall (or at least experienced trend growth). Column 1 presents a regression with just the subsidiary count as the regressor. The estimated $\beta_{1}$ is negative and significant. The 
coefficient maintains its overall significance even as we add both family and branch controls (columns 2 through 5). Instead of reducing the importance of complexity, the added controls increase the point estimate roughly by about thirty percent. In particular, notice that family complexity is not just a proxy of family size (column 2). Moreover, the role of family's complexity on lending sensitivity does not seem affected by an explicit control for branches' own balance sheet size (column 3). Likewise, any inference does not appear to be attributed to systematic differences in terms of holdings of liquid asset buffers (column 4). The main result on the complexity regressor is confirmed even in the more complete specification of column 5 , in which controls are included for family size, branch size, and illiquid assets.

This first batch of results is consistent with the stated conjecture. Family complexity makes the balance sheet of a bank relatively less reactive to funding its own priorities. In response to an exogenous, positive funding shock the branches of more complex families display a relatively lower lending sensitivity.

The lending aggregate, C\&I lending, is a standard investment metric for banks, but may nevertheless introduce distortions in our estimation since not all branches necessarily engage in this type of investment activity. The negative sign of the $\beta_{1}$ coefficient may result from branches of more complex family systematically focusing less on the financing of C\&I projects. To address this potential issue, we restrict the estimations to branches displaying a ratio of C\&I lending to total lending equal or greater than 5\% (a similar approach to, e.g., Kashyap and Stein, 2000). Table 4 shows the corresponding results. The estimated coefficient of the complexity regressor remains negative and significant. In fact the $\beta_{1}$ point estimate is more stable across specifications.

A focus on just C\&I lending may still be considered a potential source of bias, if there are systematic differences in investment orientation across branches belonging to families with different degrees of complexity. Consequently, we expanded our analysis to consider total lending as perhaps a better metric of investment activity. Table 5 shows the corresponding results, confirming a similar pattern of overall impact of family complexity on branches investment decision. Total lending growth is significantly less sensitive to the funding shock in branches of more complex families. 
This impact is also economically important. Using the estimate from column 5 in Table 5, we calculated the effect on lending sensitivity of an inter-quintile increase in the log count of family's subsidiaries. By performing the quantitative exercise by incremental quintile increases in subsidiaries count we allow for the possibility of non-linear effects. The results of this quantitative exercise actually display a fairly stable impact across quintiles. Increasing a family's overall subsidiaries count is associated with a decrease in total lending growth between 8 and 10 percentage points. This effect is approximately equal to between 25 and 30 percent of the median total lending growth of branches in the period prior to the FDIC-induced funding shock, and hence is economically significant.

A final observation is warranted on the significance of organizational size, once regression specifications also include controls for organizational complexity. Size, as is well known, is often a statistically significant but difficult to rationalize driver of many of the observations about bank responses to shocks. ${ }^{12}$ The results presented in Tables 3,4 , and 5 have evaluated the impact of complexity conditional on size, as measured by family's asset size. Column (6) of these tables also shows the role of size in specifications that exclude complexity measures. Interestingly, not only does our metric of complexity display an independent effect on branches balance sheet decision, but also complexity accounts for at least part of the variation otherwise attributable to size.

\section{Robustness}

Refinements to the complexity metric. The metric of complexity is the total count of subsidiaries that are owned by an organization. At the same time, we recognize that not all subsidiaries might be equivalent in "adding" complexity to the conglomerates. In particular, not all subsidiaries may equally impose on the overall liquidity management strategies of the organization, and therefore have the same relevance for the business decision of the bank affiliates. For example, if the rest of the organization operates in countries with funding conditions that highly co-move with the United States, there may be reduced scope for banks located in the United States to provide them support. To this end

${ }^{12}$ Cornett, McNutt, Strahan and Tehranian (2011) provide a nice discussion in the context of liquidity risk effects on bank balance sheets. 
we identified subsidiaries within the family that are also located in the United States, as well as affiliates in other locations but that have currencies pegged to the United States dollar. The premise is that countries with dollar currency pegs have monetary policy rates most tightly linked to the U.S. and therefore a closer co-movement of liquidity conditions, as well as financial and economic activity (see Obstfeld, Shambaugh, and Taylor 2010, and Goldberg 2013). Hence, for each bank family we construct the share of its subsidiaries that are located either in the U.S. or in countries with currencies pegged to the U.S. dollar per the Shambaugh exchange rate regime classification. ${ }^{13}$

Alternatively, an organization may own affiliates whose only reason for existence is to obscure transparency of the organizations' operations and evade regulation. Likewise, subsidiaries may be added in tax havens countries, thus engaging in activities that are expected to reduce the share of overall profits paid as taxes, but not otherwise contributing to the overall needs of the financial conglomerate. Either way, one could argue that these subsidiaries should not be factored in, or have a lower weight in affecting the business decision of the branches affiliates in the United States.

The status of countries as secrecy locations or tax evasion locations are determined based on metrics constructed by the Tax Justice Network. These metrics are based on information on the legal, administrative, regulatory, and tax structures of the secrecy jurisdictions. ${ }^{14}$

A general description of these geography-based characteristics across the parent organizations is provided in Table 6, with data sorted by quintiles.

Those financial conglomerates in the lowest quintile of affiliate counts also retain a much higher share of affiliates in their home location, at 78 percent compared with 52 percent for the highest quintiles. The share of overall affiliates within the United States

\footnotetext{
${ }^{13}$ http://www.nber.org/data/international-finance/shambaugh-exchange-rate-regimes.pdf. "Hard pegs" have exchange rate bands of $+/-2 \%$ against the U.S. dollar.

${ }^{14}$ The source materials include the OECD Tax Co-Operation Reports, the new OECD Global Forum peer review reports (where available), the U.S. State Department's Narcotics Control publication (U.S.-INCSR), anti-money laundering assessments by the Financial Action task Force and others, the IMF's financial sector assessment program and offshore financial center assessment program, as well as private sector sources, websites and legal texts from the secrecy jurisdictions concerned. For our specifications, we utilize as secrecy locations those countries given a Financial Secrecy Index rating over 75 and as tax havens those countries with scores of 90 or higher according to an index of having laws that avoid promoting tax evasion. The Appendix provides the country list. For each financial conglomerate, we compute the share of affiliates in tax and secrecy locations, excluding those in the home market.
} 
does not vary systemically across quintiles with the means ranging between 4 and 10 percent. The share of affiliates in dollar peg locations is generally between 20 and 30 percent for all but the highest quintile. Financial conglomerates that are most complex have the lowest share of affiliates in dollar peg locations. This may occur as a result of the heavy concentration of European firms in the upper quintile, with those entities having at least half of the affiliates in the euro area. By contrast, there is not as clear a pattern across quintiles in the share of affiliates in tax or secrecy locations. The quintile range is between 4 and 14 percent. Japanese banks have about 6 percent of entities in tax or secrecy locations, while UK, Canadian and Chinese conglomerates at closer to 15 percent of all affiliates.

Table 7 reports results where we augment the specification run earlier to explicitly take into account these refinements to the total subsidiaries count metric. In column 1 we ran the basic regression for C\&I lending but added the share of affiliates located in the U.S. or in U.S. dollar peg locations, and its interaction with our baseline metric of complexity. We expect that if an organization has a high count of subsidiaries overall, but a large fraction of those subsidiaries are in locations where economic and funding conditions comove closely with those in the United States, its U.S. bank branches should display - all else equal - a more independent balance sheet management from the parent organization, and hence a relatively high lending sensitivity to the funding shock. The results support this conjecture. The baseline metric of subsidiary count is still negative and significant, but the interaction term is positive and significant.

Likewise, we expect a similar countervailing effect if an organization had a high count but with a large fraction of subsidiaries that are likely established for tax or regulatory considerations. Column 2 of Table 7 shows the results of a regression where we added the share of affiliates in tax or secrecy locations. The baseline coefficient of log count remains negative and significant, while the interaction term is positive and significant. We repeated the same refinements using total lending growth as measure of investment. The results, in column 3 and 4, are consistent with the previous ones. The count of subsidiaries 
remains negative and statistically significant even with the inclusion of these geographic controls. 15

For robustness, we also have considered alternative measures of organizational complexity, some of which are more specifically focused on business complexity than geographic complexity. These metrics include: a measure of the average great-circle distance of all subsidiaries within the family, a measure of the average great-circle distance of all subsidiaries of the family that are outside the home location, the ratio of non-bank to bank subsidiary counts in the organization, the ratio of financial subsidiaries to total counts, a Herfindahl index constructed over 9 categories of business industries to which subsidiaries are assigned, a Herfindahl constructed over 4 categories of only the financial sector subsidiaries of the organization, an indicator variable for whether the highholder has a commercial bank in the United States, the ratio of US branch assets to total highholder assets, and the ratio of US commercial bank assets to highholder assets. Most of the organizational complexity measures are described in detail in Cetorelli and Goldberg (2014), and respective values by quintile are shown in Appendix Table 1. Inclusion of the respective metrics in regression specifications for total loans does not qualitatively change the results for the baseline role of complexity in moderating bank responses to funding shocks (Appendix Table 2).

Differential trends? A possible objection to the results shown so far is that organizational complexity does not have an impact on the lending sensitivity to funding shocks, but that those U.S. bank branches that are part of more complex organization - for whatever reason - are simply on a relatively more negative (or less positive) trend in lending growth. In this case the regression results would be just picking up that trend differential, with no inference to be made in terms of sensitivity to funding shocks due to organizational complexity.

\footnotetext{
${ }^{15}$ Some of the countries included in the tax and secrecy list are locations that objectively can be considered as legitimate "economic" destination. In separate regressions we used a modified count of tax and secrecy location, "filtering out" those countries that appeared in the WTO list of leading exporters and importers in world merchandise trade for 2012 (France Hong Kong, Ireland, Malaysia, Netherlands, Saudi Arabia, Singapore, Switzerland, United Arab Emirates). The results, not shown, were qualitatively similar.
} 
It may very well be the case that branches in more complex families exhibit a lower trend in lending growth overall. However, the point of our empirical analysis is to test whether there is a discrete change in whichever trend differential after the implementation of the FDIC ruling. We test this conjecture by switching from the pre/post regression specification to a full blown time series, panel analysis. With this alternative approach, the left hand side variable is a quarterly lending growth, and on the right hand side we include the metric of organizational complexity, any other organization or branch control, as before. Now we can also specifically add terms of interactions between the complexity measure and indicator variables for the quarters post FDIC implementation. We then test directly if there is a significant divergence from trend in response to the associated funding shock. The associated specification is given by:

$$
\begin{aligned}
\Delta Y_{\frac{t-t-1}{t}-1}^{i j}= & \alpha+\beta_{0} \cdot \operatorname{size}_{t-1}^{i, H H}+\sum_{k=1}^{11}\left(\beta_{k} \cdot \operatorname{counts}_{t-k}^{i, H H}+\beta_{2} \cdot \operatorname{counts}_{t-k}^{i, H H} \cdot \text { post }\right) \\
& +\beta_{3} \text { controls }+\varepsilon_{t}^{i}
\end{aligned}
$$

Table 8 presents the results of time series specifications (2), using total lending growth as dependent variable. It includes the same variables as in Table 8, hence the count metric of complexity, the other organizational and branch level controls and the additional geography-based terms of interactions. For convenience and ease of exposition, we report the results of the full specifications in a table in the appendix. The results in Table 8 instead report, for the quarters post FDIC implementation, the cumulative quarterly effect and its corresponding significance (this is simply the cumulative sum of the estimated coefficients of the terms of interaction of subsidiary count with the post FDIC dummies, and their corresponding F-tests). This is a way to capture the lending response to a funding shock that acknowledges that the impact may not occur instantaneously. As there may be mechanical lags in a lending response, the response may grow over time. This approach is essentially the same as that followed by Kashyap and Stein, 2000 in their seminal work on the bank lending channel. 
Column 1 presents the baseline, time series extension from the specifications in Table 8. In addition to all the variables mentioned above, the specification also includes a full set of quarterly indicator variables to control for generic effects related to any specific point in time. As the results indicate, the branches of more complex organizations display a relatively more negative trend in lending growth, as shown by the estimated coefficient of the log count regressor. However, post FDIC, the lending sensitivity diminishes significantly. The cumulative sums of the coefficients of the terms of interactions are negative and monotonically increasing, and become statistically significant after the fourth quarter post implementation. The subset of results reported in the table show that the gap between loan growth rates is evident for more than 2 years after the shock.

To further push the test for cumulative effects and differences across banks by complexity, we ran an alternative specification dropping the metric of subsidiary count and including instead family fixed effects. Trend patterns in lending growth could be driven by whichever family-specific factor, with complexity just being a proxy. With the matrix of indicator variables the effect of the subsidiary count variable cannot be identified. However, identification is still viable for the effect of complexity's interaction with the quarterly dummies post FDIC ruling. As the results in Column 2 show, the cumulative estimated coefficients of these terms of interaction have a similar pattern in terms of sign and significance. Overall, the complexity of the family renders bank branches in the United States less sensitive to own funding shocks, with this result not confounded by a simple structural difference in lending growth.

Concomitant events and spurious factors. An alternative concern may be that perhaps there is indeed a discernible change in lending growth after the FDIC ruling, but it may be driven by concomitant events occurring outside of the United States, in a way that is correlated with the metric of complexity of the family organization in our sample. For instance, it is possible that the organizations with branches in the U.S. that are more complex are also concentrated in regions of the world that around the same time of the FDIC ruling were experiencing changes in macroeconomic conditions that would lead those branches to change their own lending. A possible story is that there is a negative shock in the country of origin of the more complex families and the branches in the U.S. divert balance sheet 
resources, activating an internal capital market transfer. Finding evidence of such dynamics would confound interpretation of the conjectured role of complexity.

We run a battery of robustness tests to take into account this alternative story. First, we construct an indicator variable of geographic regions, to allow for potential correlation between complexity and specific parts of the world. Table 8 column 3 shows the results of an augmented specification to that in column 1, where we add these indicator variables. The cumulative effect post FDIC ruling shows a similar pattern as before. Next, we explicitly acknowledge the possibility of specific problems in given countries right around the time of the FDIC implementation. This is a highly plausible critique, as the experiment is around the time when some peripheral European countries were experiencing extensive difficulties. In column 4 we include an indicator variable for the GIIPS countries (Greece, Ireland, Italy, Portugal and Spain). The results on the estimated cumulative coefficients are substantively unchanged. Next, and to push even further the issue of problems in the countries of origin of the family organizations, we include in our regression analysis a measure of country GDP growth and a measure of short term interest rates, to control for country-specific, time-varying macroeconomic and funding conditions. As shown in column 5 , the inclusion of these controls does not affect the estimation and significance of the cumulative effects post FDIC ruling.

\section{Concluding Remarks}

Financial conglomerates vary tremendously in both size and organizational complexity. We provide evidence that, conditional on size, there are real economic consequences of complexity for the management of the individual entities within the financial conglomerates. Banks in institutions with more subsidiaries manage their balance sheets taking into account the potential needs of their conglomerate parents. Consequently they exhibit significantly reduced investment sensitivity to changes in own funding conditions. Complexity alters the balance sheet composition and response to funding shocks - both to external borrowers and within the conglomerate - by as much as a third. Our evidence is consistent with the view that organizational complexity imposes a degree of subordination on the business model of its subsidiaries and accords with established contributions in 
organizational theory (Rajan and Zingales 2000, 2001a, 2001b; Stein 2002, and many others) and with empirical studies of decisions made across multi-unit nonfinancial firms (e.g. Ozbas and Scharfstein 2009).

Our conclusions are also a natural complement to a body of evidence being established around active organizational liquidity management within global banks. Funds flow internally between the head office and its foreign branches in response to U.S. funding shocks. Moreover, the pattern of net flows within a bank and across it branches reflects funds circulating according to the prevalent business model assigned to each branch, with some branches acting as funding sources, and others as investment destinations. The new evidence is complementary, in that banks react less in response to local shocks if the broader organization to which they belong is more complex. A corollary is that these same banks may respond more to a shock to the non-bank part of the broader conglomerate to which they belong, with greater overall activation of internal capital markets.

Though this paper establishes evidence that organizational complexity matters for the business of a bank affiliate, we do not have anything to say on how financial conglomerates evolve into more or less complex forms in the first place. We take the decision on organizational form as exogenous to the events around the FDIC announcement, which is plausible. Likewise, we take as pre-determined both the choice of entry by a foreign banking organization into the United States and the specific decision to enter by establishing a bank branch. We do however take into account the extent to which a parent organization is also in the U.S. with other entities besides bank branches. And finally, we are cognizant of the fact that while we are focusing on organizational complexity, our measure of subsidiary count may just be proxying for overall organizational size. Our data, however, allows us to evaluate the impact of complexity conditional on size, as measured by family's asset size, and we show not only that our metric of complexity displays an independent effect on branches balance sheet decision, but also that complexity accounts for at least part of the variation otherwise attributable to size.

Policy discussions have identified the "business, structural and operational complexity" of global banking organizations as warranting more policy and research attention, along with the size of these organizations. Complexity, along with institution size, 
global presence, and interconnectedness, are argued to contribute to the global systemic importance of a bank and the potential costs of failure on the global banking system and the wider economy (Basel Committee 2013). We provide the first concrete evidence that complexity is associated with behavioral differences in the entities within the financial organization. These entities show marginal subordination of their own balance sheet to the needs of the organization. What remains to be established are the broader consequences of such complexity for aggregate welfare and financial stability. These considerations are critical for optimal policy, as the modern financial system contains fewer simple banks and more complex financial conglomerates.

\section{References}

Aghion, P. and J. Tirole. 1997. "Formal and Real Authority in Organizations." Journal of Political Economy, 105(1) , 1-29.

Basel Committee on Banking Supervision. 2013. "Global systemically important banks: updated assessment methodology and the higher loss absorbency requirement" Bank for International Settlement (July).

Cetorelli, N. and L. Goldberg. 2011. "Global Banks and International Shock Transmission: Evidence from the Crisis." IMF Economic Review, 59(1), 41-76.

Cetorelli, N. and L. Goldberg. 2012a. "Banking Globalization and Monetary Transmission." Journal of Finance, 67(5), 1811-1843.

Cetorelli, N. and L. Goldberg. 2012b. "Follow the Money: Quantifying Domestic Effects of Foreign Bank Shocks in the Great Recession." American Economic Review, 102(3), 213-218.

Cetorelli, N. and L. Goldberg. 2012c. "Liquidity Management of U.S. Global Banks: Internal Capital Markets in the Great Recession." Journal of International Economics, 88(2), 299-311.

Cetorelli, N. and L. Goldberg. 2014. "Measures of Global Bank Complexity." Federal Reserve Bank of New York Economic Policy Review, 20(2), 107-126.

Cetorelli, N., J. McAndrews, and J. Traina. 2014. "Evolution in Bank Complexity." Federal Reserve Bank of New York Economic Policy Review, 20(2), 85-106.

Cornett, M., J. McNutt, P. Strahan, and H. Tehranian. 2011. "Liquidity Risk Management and Credit Supply in the Financial Crisis." Journal of Financial Economics, 101(2), 297312.

Düwel, C. and R. Frey. 2012. "Competition for Internal Funds Within Multinational Banks: Foreign Affiliate Lending in the Crisis." Bundesbank Discussion Paper, No 19/2012, Economic Research Centre, Deutsche Bundesbank. 
Federal Deposit Insurance Corporation. 2011. 12 CFR Part 327, RIN 3064-AD66, Assessments, large bank pricing. Federal Register 76(38), 10672-733.

Goldberg, L. 2013. "Banking Globalization, Transmission, and Monetary Policy Autonomy." Sveriges Riksbank Economic Review, 3, 161-193.

Gruenberg, M. 2011. "Statement of Martin J. Gruenberg, Acting Chairman, Federal Deposit Insurance Corporation on Implementation of the Dodd-Frank Act before the Committee on Banking, Housing and Urban Affairs, United States Senate; 538 Dirksen Senate Office Building." December 6, 2011.

Hart, O. and J. Moore. 2005. "On the Design of Hierarchies: Coordination versus Specialization." Journal of Political Economy, 113(4), 675-702.

Herring, Richard and Jacopo Carmassi. 2015. Corporate Structures, Transparency and Resolvability of Global Systemically Important Banks. Manuscript.

Kashyap, A. and J. Stein. 2000. "What Do A Million Observations on Banks Say About the Transmission of Monetary Policy?" American Economic Review, 90(3), 407-428.

Kerl, C. and C. Koch. 2015. "International Banking and Liquidity Risk Transmission: Evidence from Germany." IMF Economic Review, 63(3), 496-514.

Kreicher, L., R. McCauley, and P. McGuire. 2014. "The 2011 FDIC Assessment on Banks' Managed Liabilities: Interest Rate and Balance Sheet Responses." Taxation and Regulation of the Financial Sector. Cambridge: MIT Press.

Milgrom, P. 1988. "Employment Contracts, Influence Activities, and Efficient Organization Design." Journal of Political Economy, 96(1), 42-60.

Milgrom, P. and J. Roberts. 1988. "An Economic Approach to Influence Activities in Organizations." American Journal of Sociology, 94(Supplement), 154-179.

Obstfeld, M., J. Shambaugh, and A. Taylor. 2010. "Financial Stability, the Trilemma, and International Reserves." American Economic Association Journal: Macroeconomics, 2(2), 57-94.

Ozbas, O. and D. Scharfstein. 2010. "Evidence on the Dark Side of Internal Capital Markets." Review of Financial Studies, 23(2), 581-599.

Pawłowska M., D. Serwa, and S. Zajączkowski. 2015. "International Banking and Liquidity Risk Transmission: Evidence from Poland." IMF Economic Review, 63(3), 585-605.

Rajan, R. and L. Zingales. 2000. "The Governance of the New Enterprise." Corporate Governance, Theoretical \& Empirical Perspectives X. Vives ed., Cambridge: Cambridge University Press.

Rajan, R. and L. Zingales. 2001a. "The Firm as a Dedicated Hierarchy: A Theory of the Origins and Growth of Firms." The Quarterly Journal of Economics, 116(3), 805-851.

Rajan, R. and L. Zingales. 2001b. "The Influence of the Financial Revolution on the Nature of Firms." American Economic Review, 91(2), 206-211.

Stein, J. 2002. "Information Production and Capital Allocation: Decentralized versus Hierarchical Firms." Journal of Finance, 57(5), 1891-1921. 
Tax Justice Network. 2014 Financial Secrecy Index. http://www.financialsecrecyindex.com. 2014.

Wong, E., A. Tsang, and S. Kong. 2015. "International Banking and Liquidity Risk Transmission: Evidence from Hong Kong S.A.R." IMF Economic Review, 63(3), 515541. 


\section{Chart 1 Counts of affiliated entities within FBOs}

Foreign Banking Organizations and Affiliate Count, by Quintile (2012:Q4)
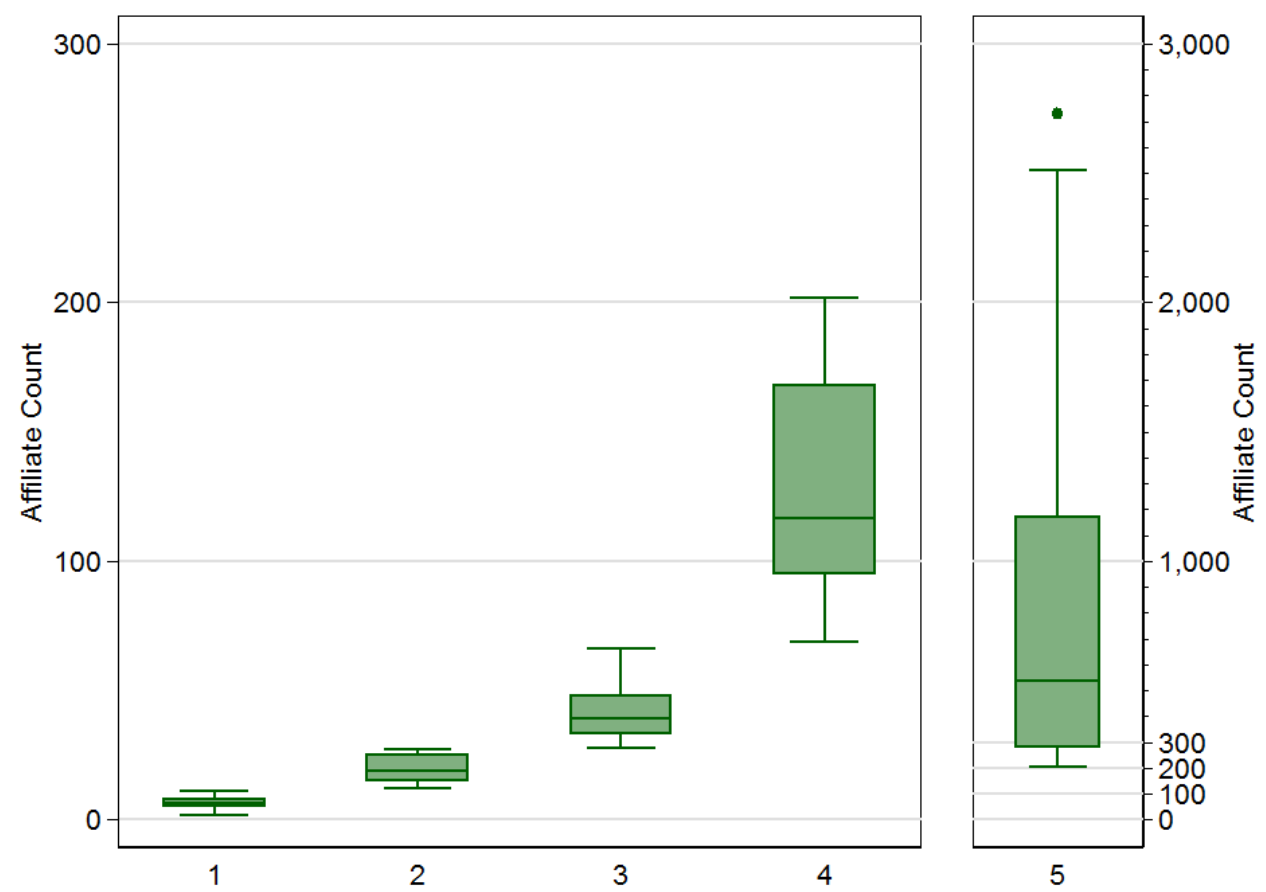

Note: Quintiles are indicated along the x-axis. Source: Bankscope. 


\section{Chart 2 Counts of affiliated entities and Asset size Across FBOs}

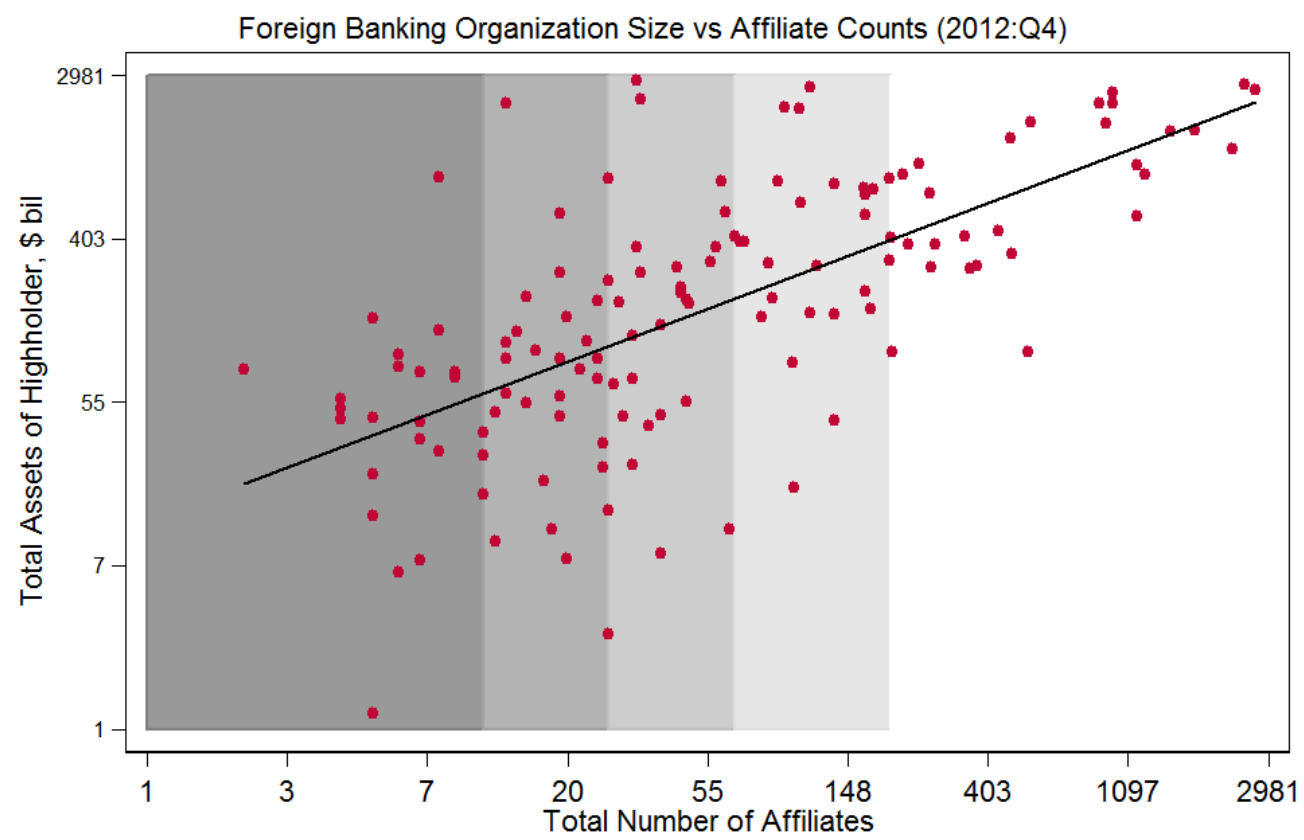

Slope of Fit Line $=0.673^{\star \star \star}$

$\mathrm{R}$ Squared $=0.436$

Gray shaded areas indicate quintiles of count. Tick marks on the $x$-axis and $y$-axis are spaced using log scale. X-axis labels indicate total number of affiliates per highholder. Y-axis labels indicate total assets per highholder. Sources: Bankscope, Capital IQ. 
Table 1: Descriptive Statistics: US Branches of FBOs vs US Commercial Banks 2010

\begin{tabular}{l|ccc|ccc}
\hline & \multicolumn{4}{|c|}{ US Branches of FBOs } & \multicolumn{3}{c}{ Commercial Banks of US Global } \\
& p25 & p50 & p75 & p25 & p50 & p75 \\
\hline Assets (mil) & 414 & 1316 & 11618 & 409 & 1468 & 11994 \\
Loan Share & 0.13 & 0.39 & 0.68 & 0.43 & 0.68 & 0.77 \\
C\&I Loan Share & 0.03 & 0.20 & 0.40 & 0.05 & 0.10 & 0.14 \\
Funding (Deposit) Share & 0.13 & 0.45 & 0.67 & 0.60 & 0.76 & 0.83 \\
\hline Observations & \multicolumn{4}{|c|}{147} & & 189 \\
\hline
\end{tabular}

Note: All shares refer to share of total assets. For the U.S. branches of FBOs, the balance sheet information for families with more than one U.S. branch is aggregated across all branches up to their common bank parent. For commercial banks of U.S. global BHC's, the sample is comprised of commercial banks that belong to US highholders that also have affiliates in at least one other country. Sources: Call Reports, FFIEC 002. 
Table 2: Foreign Banking Organizations with US Branches, by Highholder region (2010:Q4)

\begin{tabular}{|c|c|c|c|c|c|c|c|}
\hline \multirow[b]{2}{*}{$\begin{array}{l}\text { Highholder } \\
\text { Region }\end{array}$} & \multicolumn{4}{|c|}{ Highholder Data } & \multicolumn{3}{|c|}{ US Branch Data } \\
\hline & $\begin{array}{l}\text { Number of } \\
\text { Highholders }\end{array}$ & $\begin{array}{l}\text { Highholder } \\
\text { Total } \\
\text { Assets } \\
\text { (Billions of } \\
\text { Dollars) }\end{array}$ & $\begin{array}{c}\text { Total } \\
\text { Affiliate } \\
\text { Count }\end{array}$ & $\begin{array}{c}\text { Median } \\
\text { Affiliate } \\
\text { Count }\end{array}$ & $\begin{array}{c}\text { Number of } \\
\text { U.S. } \\
\text { Branches }\end{array}$ & $\begin{array}{c}\text { Branch } \\
\text { Total } \\
\text { Assets } \\
\text { (Billions of } \\
\text { Dollars) }\end{array}$ & $\begin{array}{c}\text { Branch } \\
\text { Median } \\
\text { Assets } \\
\text { (Billions of } \\
\text { Dollars) }\end{array}$ \\
\hline Euro Area & 27 & 21,259 & 18252 & 356 & 42 & 712 & 10 \\
\hline United Kingdom & 4 & 6,662 & 3747 & 940 & 10 & 204 & 32 \\
\hline Japan & 8 & 5,886 & 335 & 14 & 16 & 309 & 10 \\
\hline China & 5 & 6,231 & 208 & 33 & 8 & 18 & 1 \\
\hline Switzerland & 2 & 2,514 & 720 & 360 & 6 & 134 & 67 \\
\hline Canada & 7 & 2,983 & 767 & 90 & 15 & 245 & 30 \\
\hline Other Americas & 18 & 1,324 & 499 & 15 & 22 & 29 & 1 \\
\hline Other Asia & 37 & 3,849 & 1132 & 25 & 57 & 48 & 1 \\
\hline Other & 24 & 5,264 & 2921 & 43 & 28 & 160 & 1 \\
\hline All & 132 & 55,973 & 28,581 & 39 & 204 & 1,858 & 1 \\
\hline
\end{tabular}

Note: Number of Highholders is the count of Foreign Banking Organizations by each geographical region. Highholder Total Assets is the sum of total assets of all highholders in a region. Total Affiliate Count is the sum of affiliates across all highholders in a region. Median Affiliate Count is the count of affiliates of the median highholder by count in a region. Number of U.S. Branches is the total number of branches in operation in the U.S. belonging to highholders of each region. Branch Total Assets is the sum of total assets of all branches of highholders from each region. Branch Median Assets are calculated by aggregating across all branches up to their common bank parent and then taking the median by highholder region. Sources: Bankscope, Capital IQ, FFIEC 002. 
Table 3 C\&I Lending Growth

\begin{tabular}{lllllll}
\hline & \multicolumn{1}{c}{$(1)$} & \multicolumn{1}{c}{$(2)$} & \multicolumn{1}{c}{$(3)$} & \multicolumn{1}{c}{$(4)$} & \multicolumn{1}{c}{$(5)$} & $(6)$ \\
Log Count & $-0.067^{* * *}$ & $-0.093^{* * *}$ & $-0.073^{* *}$ & $-0.066^{* * *}$ & $-0.090^{* * *}$ & \\
Log HH Assets & $(0.024)$ & $(0.029)$ & $(0.033)$ & $(0.023)$ & $(0.033)$ & \\
& & 0.041 & & & 0.051 & -0.026 \\
Log Branch Assets & & $(0.033)$ & & & $(0.037)$ & $(0.029)$ \\
& & & 0.008 & & -0.011 & \\
Liquid Assets Share & & & $(0.029)$ & & $(0.033)$ & \\
& & & & 0.096 & 0.124 & \\
Constant & $0.425 * * *$ & $0.320^{* *}$ & 0.276 & $0.389 * * *$ & 0.459 & $0.285^{*}$ \\
& $(0.113)$ & $(0.152)$ & $(0.553)$ & $(0.127)$ & $(0.579)$ & $(0.161)$ \\
Observations & 130 & 130 & 130 & 130 & 130 & 130 \\
Adjusted R2 & 0.048 & 0.050 & 0.041 & 0.042 & 0.039 & -0.000 \\
\hline * p<0.10 ** $\mathrm{p}<0.05 * * * \mathrm{p}<0.01$ & & & & & \\
\hline
\end{tabular}

Note: Growth in C\&l loans is winsorized at +/-100\% growth. Log HH Assets represents the log of highholder assets. Log Count represents the log of the number of highholder affiliates. Log Branch Assets represents the log of branch assets. Liquid Asset Share is the ratio of liquid assets (cash and securities) to total assets. The C\&I loans information for families with more than one U.S. branch is aggregated across all branches up to their common highholder. Standard errors are clustered at the highholder level. Sources: Bankscope, Capital IQ, FFIEC 002. 
Table 4 C\&I Lending Growth (Branches where C\&I lending >= 5\%)

\begin{tabular}{lllllll}
\hline & \multicolumn{1}{c}{$(1)$} & \multicolumn{1}{c}{$(2)$} & \multicolumn{1}{c}{$(3)$} & \multicolumn{1}{c}{$(4)$} & \multicolumn{1}{c}{$(5)$} & $(6)$ \\
Log Count & $-0.082^{* * *}$ & $-0.088^{* * *}$ & $-0.079^{* *}$ & $-0.082^{* * *}$ & $-0.085^{* *}$ & \\
& $(0.022)$ & $(0.031)$ & $(0.033)$ & $(0.022)$ & $(0.035)$ & \\
Log HH Assets & & 0.009 & & & 0.018 & $-0.060^{* *}$ \\
& & $(0.034)$ & & & $(0.036)$ & $(0.027)$ \\
Log Branch Assets & & & -0.004 & & -0.011 & \\
& & & $(0.029)$ & & $(0.032)$ & \\
Liquid Assets Share & & & & 0.061 & 0.078 & \\
& & & & $(0.207)$ & $(0.209)$ & \\
Constant & $0.507^{* * *}$ & $0.481^{* * *}$ & 0.587 & $0.485^{* * *}$ & 0.630 & $0.487^{* * *}$ \\
& $(0.104)$ & $(0.141)$ & $(0.546)$ & $(0.120)$ & $(0.568)$ & $(0.150)$ \\
Observations & 123 & 123 & 123 & 123 & 123 & 123 \\
Adjusted R2 & 0.079 & 0.072 & 0.072 & 0.072 & 0.058 & 0.028 \\
\hline$* p<0.10 * * p<0.05 * * * p<0.01$ & & & & & \\
\hline
\end{tabular}

Note: Growth in C\&l loans is winsorized at $+/-100 \%$ growth. The sample is restricted to only branches where C\&I lending is greater than or equal to $5 \%$. Log HH Assets represents the log of highholder assets. Log Count represents the log of the number of highholder affiliates. Log Branch Assets represents the log of branch assets. Liquid Asset Share is the ratio of liquid assets (cash and securities) to total assets. The C\&I loans information for families with more than one U.S. branch is aggregated across all branches up to their common highholder. Standard errors are clustered at the highholder level. Sources: Bankscope, Capital IQ, FFIEC 002. 
Table 5 Total Lending Growth

\begin{tabular}{lllllll}
\hline & \multicolumn{1}{c}{$(1)$} & \multicolumn{1}{c}{$(2)$} & \multicolumn{1}{c}{$(3)$} & \multicolumn{1}{c}{$(4)$} & \multicolumn{1}{c}{$(5)$} & $(6)$ \\
Log Count & $-0.047^{* *}$ & $-0.077^{* * *}$ & -0.049 & $-0.045^{* *}$ & $-0.069^{* *}$ & \\
& $(0.023)$ & $(0.028)$ & $(0.034)$ & $(0.022)$ & $(0.033)$ & \\
Log HH Assets & & 0.044 & & & $0.063^{*}$ & -0.010 \\
& & $(0.029)$ & & & $(0.032)$ & $(0.025)$ \\
Log Branch Assets & & & 0.002 & & -0.022 & \\
& & & $(0.027)$ & & $(0.031)$ & \\
Liquid Assets Share & & & & 0.084 & 0.134 & \\
& & & & $(0.186)$ & $(0.183)$ & \\
Constant & $0.358^{* * *}$ & $0.251^{*}$ & 0.314 & $0.322^{* * *}$ & 0.545 & 0.220 \\
& $(0.103)$ & $(0.133)$ & $(0.491)$ & $(0.108)$ & $(0.521)$ & $(0.134)$ \\
Observations & 138 & 138 & 138 & 138 & 138 & 138 \\
Adjusted R2 & 0.022 & 0.028 & 0.015 & 0.017 & 0.021 & -0.006 \\
\hline$*$ p $<0.10 * * p<0.05 * * *$ \\
\hline
\end{tabular}

Note: Growth in total loans is winsorized at $+/-100 \%$ growth. Log HH Assets represents the log of highholder assets. Log Count represents the log of the number of highholder affiliates. Log Branch Assets represents the log of branch assets. Liquid Asset Share is the ratio of liquid assets (cash and securities) to total assets. The total loans information for families with more than one U.S. branch is aggregated across all branches up to their common highholder. Standard errors are clustered at the highholder level. Sources:

Bankscope, Capital IQ, FFIEC 002. 
Table 6: Geography of Affiliates of Foreign Financial Conglomerates, by Quintile

\begin{tabular}{ll|lllll}
\hline & & \multicolumn{5}{|c}{ Affiliate Count Quintile } \\
& & $\mathbf{1}$ & $\mathbf{2}$ & $\mathbf{3}$ & $\mathbf{4}$ & $\mathbf{5}$ \\
\hline \multirow{3}{*}{ Avg Share Across } & Parent Home Country & 0.78 & 0.57 & 0.60 & 0.52 & 0.52 \\
Parents* & US Affiliates & 0.08 & 0.04 & 0.10 & 0.08 & 0.05 \\
& US + Dollar Hard Peg & 0.22 & 0.28 & 0.27 & 0.19 & 0.08 \\
Weighted Distance & Tax/Secrecy & 0.04 & 0.10 & 0.14 & 0.12 & 0.08 \\
from Parent (km) & All Affiliates & 6561 & 5463 & 5292 & 5403 & 3172 \\
\multirow{2}{*}{ Avg Across Parents } & Affiliate Count & 7 & 2179 & 2186 & 2819 & 1412 \\
& Highholder Assets (\$Bil) & 87 & 195 & 387 & 129 & 868 \\
\hline
\end{tabular}

Note: *Shares are calculated by first dropping all affiliates with missing country information. All information comes from 2012:Q4. Sources: Bankscope, Capital IQ, CEPII, FFIEC 002, Shambaugh Exchange Rate Regime Classifications, Tax Justice Network. 
Table 7 Lending Growth and Organizational Complexity: Robustness to Geography

\begin{tabular}{|c|c|c|c|c|}
\hline & \multirow{2}{*}{\multicolumn{2}{|c|}{ (1) }} & \multirow{2}{*}{\multicolumn{2}{|c|}{$\begin{array}{cc}(3) & (4) \\
& \text { Total Loans }\end{array}$}} \\
\hline & & & & \\
\hline Log Count & $\begin{array}{l}-0.126^{* * *} \\
(0.034)\end{array}$ & $\begin{array}{l}-0.129 * * * \\
(0.036)\end{array}$ & $\begin{array}{l}-0.093 * * * \\
(0.035)\end{array}$ & $\begin{array}{l}-0.096 * * * \\
(0.035)\end{array}$ \\
\hline Log HH Assets & $\begin{array}{l}0.030 \\
(0.037)\end{array}$ & $\begin{array}{l}0.051 \\
(0.037)\end{array}$ & $\begin{array}{l}0.050 \\
(0.034)\end{array}$ & $\begin{array}{l}0.059^{*} \\
(0.032)\end{array}$ \\
\hline Log Branch Assets & $\begin{array}{l}-0.018 \\
(0.034)\end{array}$ & $\begin{array}{l}-0.019 \\
(0.033)\end{array}$ & $\begin{array}{l}-0.024 \\
(0.032)\end{array}$ & $\begin{array}{l}-0.027 \\
(0.031)\end{array}$ \\
\hline Liquid Assets Share & $\begin{array}{l}0.137 \\
(0.194)\end{array}$ & $\begin{array}{l}0.097 \\
(0.202)\end{array}$ & $\begin{array}{l}0.138 \\
(0.185)\end{array}$ & $\begin{array}{l}0.126 \\
(0.183)\end{array}$ \\
\hline US+PegH Share & $\begin{array}{l}-1.199 * * \\
(0.495)\end{array}$ & & $\begin{array}{l}-0.759 * \\
(0.384)\end{array}$ & \\
\hline USPegHXLnCount & $\begin{array}{l}0.341^{* * *} \\
(0.124)\end{array}$ & & $\begin{array}{l}0.242 * * \\
(0.095)\end{array}$ & \\
\hline Tax+Sec Share & & $\begin{array}{l}-2.086 \\
(1.274)\end{array}$ & & $\begin{array}{l}-1.081 \\
(1.098)\end{array}$ \\
\hline TaxSecXLnCount & & $\begin{array}{l}0.558^{*} \\
(0.296)\end{array}$ & & $\begin{array}{l}0.380 \\
(0.262)\end{array}$ \\
\hline Constant & $\begin{array}{l}0.830 \\
(0.613)\end{array}$ & $\begin{array}{l}0.764 \\
(0.573)\end{array}$ & $\begin{array}{l}0.741 \\
(0.563)\end{array}$ & $\begin{array}{l}0.730 \\
(0.525)\end{array}$ \\
\hline Observations & 130 & 130 & 138 & 138 \\
\hline Adjusted $R^{\wedge} 2$ & 0.084 & 0.053 & 0.036 & 0.026 \\
\hline
\end{tabular}

Note: All dependent variables are winsorized at +/-100\% growth. Log HH Assets represents the log of highholder assets. Log Count represents the log of the number of highholder affiliates. Log Branch Assets represents the log of branch assets. Liquid Asset Share is the ratio of liquid assets (cash and securities) to total assets. US+PegH Share is the share of affiliates located in the U.S. or in U.S. dollar hard peg locations. Tax+Sec Share is the share of affiliates in tax or secrecy locations. For all dependent variables, the balance sheet information for families with more than one U.S. branch is aggregated across all branches up to their common highholder. Standard errors are clustered at the highholder level.

Sources: Bankscope, Capital IQ, FFIEC 002. 
Table 8 Time Series Panels of Total Loan Growth Complexity, and Geography

\begin{tabular}{|c|c|c|c|c|c|}
\hline & (1) & $(2)$ & (3) & (4) & $(5)$ \\
\hline \multirow[t]{2}{*}{ Log Count } & $-0.014^{* *}$ & & -0.002 & $-0.012^{* *}$ & $-0.015^{* *}$ \\
\hline & $(-2.42)$ & & $(-0.24)$ & $(-2.10)$ & $(-2.48)$ \\
\hline \multirow[t]{2}{*}{ Log HH Assets (lag 1Q) } & $0.020 * * *$ & $0.034 * *$ & $0.021 * * *$ & $0.022 * * *$ & $0.020 * * *$ \\
\hline & $(3.26)$ & $(2.32)$ & $(2.66)$ & (3.39) & $(3.25)$ \\
\hline \multirow[t]{2}{*}{ Log Branch Assets (lag 1Q) } & $-0.006 *$ & $-0.023 * *$ & -0.007 & $-0.008 * *$ & -0.006 \\
\hline & $(-1.67)$ & $(-2.45)$ & $(-1.64)$ & $(-2.07)$ & $(-1.48)$ \\
\hline \multirow[t]{2}{*}{ Liquid Asset Share (lag 1Q) } & 0.053 & $0.216 * * *$ & $0.056^{*}$ & 0.048 & 0.041 \\
\hline & $(1.61)$ & $(4.27)$ & $(1.96)$ & $(1.46)$ & $(1.31)$ \\
\hline \multirow[t]{2}{*}{ GDP Growth (lag 1Q) } & & & & & -0.465 \\
\hline & & & & & $(-1.52)$ \\
\hline \multirow[t]{2}{*}{ Interest Rate (lag 1Q) } & & & & & $0.005 * *$ \\
\hline & & & & & $(2.26)$ \\
\hline \multirow[t]{2}{*}{ Constant } & 0.044 & $0.885^{* * *}$ & -0.036 & 0.076 & 0.005 \\
\hline & $(0.67)$ & $(4.61)$ & $(-0.50)$ & $(1.12)$ & $(0.08)$ \\
\hline Observations & 2591 & 2591 & 2591 & 2591 & 2591 \\
\hline Adjusted R2 & 0.026 & 0.083 & 0.043 & 0.027 & 0.030 \\
\hline \multicolumn{6}{|c|}{ Cumulative Growth Effect after FDIC Shock } \\
\hline Q1 & -.015 & -.016 & -.015 & -.015 & -.013 \\
\hline Q1 to Q4 & -.057 & $-.076^{*}$ & -.057 & -.057 & -.051 \\
\hline Q1 to Q8 & $-.123 * *$ & $-.163 * *$ & $-.118^{*}$ & $-.121 * *$ & $-.111^{*}$ \\
\hline Q1 to Q11 & $-.145 * *$ & $-.213 * * *$ & $-.137^{*}$ & $-.14 * *$ & $-.125^{*}$ \\
\hline \multicolumn{6}{|c|}{ Control Variables } \\
\hline US+PegH and Tax+Sec Shares & $\mathrm{x}$ & $\mathrm{x}$ & $x$ & $x$ & $x$ \\
\hline Time Dummies & $x$ & $x$ & $x$ & $x$ & $x$ \\
\hline Family Dummies & & $x$ & & & \\
\hline Region Dummies & & & $x$ & & \\
\hline GIIPS Dummies & & & & $x$ & \\
\hline
\end{tabular}

$* \mathrm{p}<0.10 * * \mathrm{p}<0.05 * * * \mathrm{p}<0.01$

Note: The dependent variable is growth in total loans, winsorized at $+/-100 \%$ growth. All regressions include date fixed effects. Log $\mathrm{HH}$ Assets represents the log of highholder assets. Log Count represents the log of the number of highholder affiliates. Log Branch Assets represents the log of branch assets. Liquid Asset Share is the ratio of liquid assets (cash and securities) to total assets. Log HH Assets, Log Branch Assets, Liquid Asset Share, GDP Growth, and Interest Rate are all lagged by 1 quarter. US+PegH Share is the share of affiliates located in the U.S. or in U.S. dollar hard peg locations. Tax+Sec Share is the share of affiliates in tax or secrecy locations. GIIPS countries are Greece, Ireland, Italy, Portugal, and Spain. The total loans information for families with more than one U.S. branch is aggregated across all branches up to their common bank parent. Standard errors are clustered at the highholder level. Sources: Bankscope, Capital IQ, DLX Haver, FFIEC 002, IMF IFS, Shambaugh Exchange Rate Regime Classifications. 
Appendix Table 1: Complexity Measures for Foreign Financial Conglomerates, by Quintile

\begin{tabular}{cl|lllll}
\hline & & \multicolumn{5}{|c}{ Affiliate Count Quintile } \\
& & $\mathbf{1}$ & $\mathbf{2}$ & $\mathbf{3}$ & $\mathbf{4}$ & $\mathbf{5}$ \\
\hline \multirow{2}{*}{ Geography } & Geo_dist & 1376 & 2179 & 2186 & 2819 & 1412 \\
& Geo_dist_fgn & 6561 & 5463 & 5292 & 5403 & 3172 \\
& NB2B_rat & 2.49 & 2.75 & 4.13 & 7.40 & 10.37 \\
& Fin_rat & 0.76 & 0.73 & 0.69 & 0.52 & 0.32 \\
& Herf_9cat & 0.68 & 0.80 & 0.84 & 0.91 & 0.91 \\
& Herf_fin & 0.60 & 0.77 & 0.80 & 0.86 & 0.87 \\
& Has_UScb & 0.00 & 0.13 & 0.31 & 0.42 & 0.30 \\
& Br2HHassets & 0.00 & 0.00 & 0.07 & 0.02 & 0.01 \\
& UScb2HHassets & 0.03 & 0.02 & 0.03 & 0.03 & 0.03 \\
\hline
\end{tabular}

Note: Shares are calculated by first dropping all affiliates with missing country information. All information comes from 2012:Q4 except balance sheet complexity, which is averaged over the preFDIC shock period. Geo_dist is the average greater circle distance in kilometers between all subsidiaries to the highholder country. Geo_dist_fgn is the average greater circle distance in kilometers between all foreign subsidiaries and the highholder country. NB2B_rat is the ratio of nonbank to bank subsidiary counts for each highholder. Fin_rat is the ratio of financial subsidaries to all subsidiaries. Herf_9cat is a Herfindahl index constructed over 9 categories of industries to which subsidiaries are assigned. Herf_fin is a Herfindahl index constructed over 4 categories of subsidiaries in the financial sector. Has_UScb is an indicator variable that equals 1 when the highholder has a commercial bank in the U.S. Br2HHassets is the ratio of US branch assets to total highholder assets. UScb2HHassets is the ratio of US commercial bank assets to highholder assets. Sources: Bankscope, Capital IQ, CEPII, FFIEC 002, Call Reports, Shambaugh Exchange Rate Regime Classifications, Tax Justice Network. 
Appendix Table 2: Lending Growth and Geographical, Organizational, and Business Complexity

(1)

(3)

(4)

(5)

(6)

(7)

(8)

(9)

(10)

UScb2

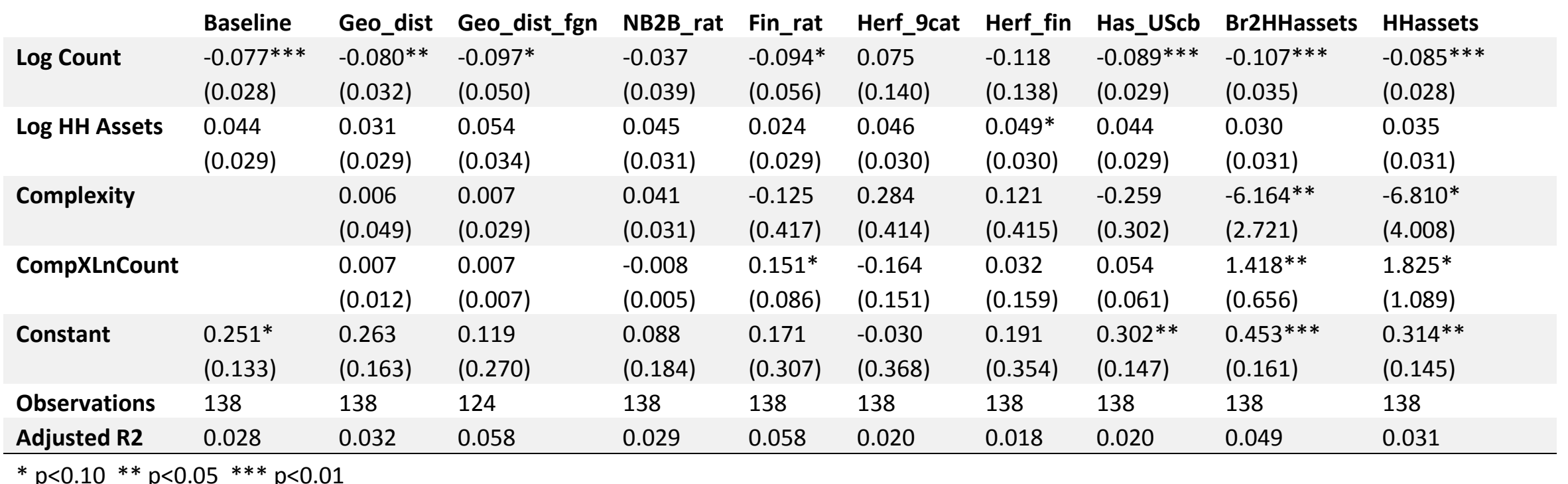

Note: The dependent variable is growth in total loans, winsorized at +/-100\% growth. Log HH Assets represents the log of highholder assets. Log

Count represents the log of the number of highholder affiliates. Geo_dist is the average greater circle distance between all subsidiaries to the highholder country. Geo_dist_fgn is the average greater circle distance between all foreign subsidiaries and the highholder country. NB2B_rat is the ratio of non-bank to bank subsidiary counts for each highholder. Fin_rat is the ratio of financial subsidiaries to all subsidiaries. Herf_9cat is a Herfindahl index constructed over 9 categories of industries to which subsidiaries are assigned. Herf_fin is a Herfindahl index constructed over 4 categories of subsidiaries in the financial sector. Has_UScb is an indicator variable that equals 1 when the highholder has a commercial bank in the U.S. Br2HHassets is the ratio of US branch assets to total highholder assets. UScb2HHassets is the ratio of US commercial bank assets to highholder assets. The total loans information for families with more than one U.S. branch is aggregated across all branches up to their common bank parent. Standard errors are clustered at the highholder level. Sources: Bankscope, Capital IQ, CEPII, FFIEC 002, Call Report. 